
\title{
Da alcoolização ao verbo: ensaio da psicodinâmica do
trabalho*
}

\section{Julia Trevisan Martins ${ }^{1}$, Maria Cristina Cescatto Bobroff ${ }^{1}$}

Nesta obra, a autora analisa a interlocução entre consumo patológico e consumo patogênico de álcool, tendo como campo de ação-pesquisa 12 anos de trabalho direto e 6 de labor indireto em uma empresa de petroquímica brasileira.

Descreve a complexidade da embriaguez e enfoca que a partir da Revolução Industrial houve um distanciamento da interpretação da embriaguez associada aos sentimentos de prazer para formatar um quadro patogênico e crônico que denomina de alcoolização utilizado como estratégia coletiva de defesa dos trabalhadores diante do sofrimento.

$\mathrm{Na}$ análise hermenêutica realizada, na estatal brasileira, identificou um número expressivo de trabalhadores em situação de alcoolização e implementou um programa de prevenção e de tratamento fundamentados na psicodinâmica do trabalho.

A autora é contundente ao afirmar que é necessária uma política governamental de trabalho que tenha como princípio o homem na sua dimensão intrapsíquica, no espaço intersubjetivo e por meio da palavra política. Assim, haveria uma diminuição dos gastos com medidas paliativas e de ações políticas assistencialistas.

Esta afirmação esta pautada em vários argumentos da psicodinâmica do trabalho ${ }^{(1-2)}$ que enfatiza ser preciso repensar as políticas dos processos organizativos do trabalho, criando ambientes nos quais todos possam discutir e buscar coletivamente estratégias que considerem os lucros frente ao mundo capitalista mas que também garantam aos trabalhadores exercerem suas atividades com o máximo de prazer e o mínimo de sofrimento.

Assim sendo, se nada for feito para alterar significativamente esta lógica, pode-se chegar ao extremo de um fenômeno brutal conhecido como suicídio ${ }^{(3)}$. Para reverter o alcoolismo advindo do trabalho deve-se substituir a competitividade e isolamento nas organizações por cooperação e solidariedade, bem como proporcionar espaço para a comunicação efetiva.

Ainda, o que a autora debate sobre as teorias administrativas clássicas aplica-se ao processo de trabalho da enfermagem que é taylorizado, sob responsabilidade do enfermeiro que, muitas vezes, não abre espaços de comunicação.

Este livro é fundamental para profissionais de diversas áreas, em especial, saúde, psicologia, psiquiatria, serviço social, enfermagem, dentre outras, visto que traz importantes reflexões sobre as implicações do trabalho.

Com relação à enfermagem, o enfermeiro necessita ser preparado para atender os alcoolistas frente às necessidades impostas pelo atual contexto do uso e abuso de álcool e de outras drogas, atuando na identificação precoce e na prevenção(4).

Por fim, destaca-se que a autora, corrobora com os pensamentos de outro pesquisador ${ }^{(5)}$ ao afirmar que somente

* Karam H. Da alcoolização ao verbo: ensaio da psicodinâmica do trabalho. Brasília: Paralelo; 2010. 384p.

${ }^{1}$ Curso de Graduação em Enfermagem, Universidade Estadual de Londrina - UEL - Londrina (PR), Brasil. 
por meio do trabalho multiprofissional, com objetivos e metas traçadas é que se pode intervir nos problemas de alcoolismo e outros que podem surgir relacionados ao sofrimento no labor.

Sugerimos a leitura desta obra brasileira que contribui para o entendimento das relações de trabalho e considera o trabalhador como um ser único, que pensa, que tem vontade própria e um valor singular que devem ser respeitados.

\section{REFERÊNCIA}

1. Dejours C. A banalização da injustiça social. $3^{\text {a }}$ Rio de Janeiro: FGV, 2000. 160p.

2. Dejours C. A loucura do trabalho: estudo de psicopatologia e psicodinâmica do trabalho. $5^{a}$ Ed. São Paulo: Cortez-Oboré, 1992.168p.

3. Dejours C, Bègue F. Suicídio e trabalho: o que fazer? Brasília: Paralelo 15, 2010.127p.

4. Vargas D, Oliveira MAF de, Luis MAV. Atendimento ao alcoolista em serviços de atenção primária à saúde: percepções e condutas do enfermeiro. Acta paul. enferm. [online]. 2010, vol.23, n.1, pp. 73-79.

5. Zimerman DE, Osório LC. Como trabalhamos com grupos. Porto Alegre: Artes Médicas, 1997. 424p. 